\title{
1 Microbial redox activity mediated anaerobic pyrite oxidation under
}

\section{2 circumneutral conditions}

3 Tong Liu ${ }^{a}$, Yutian $\mathrm{Hu}^{\mathrm{a}}$, Nan Chen ${ }^{\mathrm{a}}$, Linlin $\mathrm{Ma}^{\mathrm{a}}$, Qiaochong He ${ }^{\mathrm{b}}$, Chuanping Feng ${ }^{\text {a* }}$

4 a School of Water Resources and Environment, MOE Key Laboratory of Groundwater

5 Circulation and Environmental Evolution, China University of Geosciences (Beijing), Beijing

6 100083, P.R. China

$7{ }^{b}$ School of Environmental Engineering, Henan University of Technology, Zhengzhou, 450001,

8 P.R. China

18 " To whom correspondence should be addressed.

19 Address: No. 29, Xueyuan Road, Haidian District, Beijing, 100083, China

20 Tel: +86010 82322281; Fax: +86 01082322281

21 Email Address: fengcp@cugb.edu.cn 


\section{Abstract}

23 In modern Earth, anaerobic pyrite oxidation under circumneutral conditions also has

24 great impact on the fate of nitrate in aquifers and sediments, as well as the transportation

25 of toxic metals. However, the mechanism of how microbes mediated this process is still

26 being debated. Electrochemical analysis on pyrite cubic electrode showed that, its

27 oxidation threshold under anaerobic circumneutral conditions (ca. $200 \mathrm{mV}$ ) was much

28 lower than that at aerobic acidic conditions (ca. $650 \mathrm{mV}$ ), implying possible direct

29 pyrite oxidation by high redox potential cellular components. Sole substrate (pyrite)

30 microbial enrichment cultures with EDTA addition showed higher oxidation rate $(0.092$

$\left.31 \mathrm{~d}^{-1}\right)$ than that of EDTA-free cultures $\left(0.019 \mathrm{~d}^{-1}\right)$, suggesting that ligands producing pathway was much preferred by microbes than maintaining acidic micro-environments.

33 This hypothesis was supported by amplicon and metagenomic sequencing data, which

34 demonstrated discrepant bacteria involving iron-sulfur oxidation and metabolic

35 potentials in cultures with/without EDTA addition. A concept model was proposed

36 based on experimental data considering different reaction stages and microbial

37 communities. The results shed lights on the potential interactions between microbes and

38 pyrite, which may serve as a model for explaining subsurface pyrite oxidation and

39 optimizing anaerobic pyrite oxidation-based pollutant removal processes.

41 Keywords: sulfur cycle, anaerobic pyrite oxidation, microbial mineral transformation, 
bioRxiv preprint doi: https://doi.org/10.1101/2020.02.17.952168; this version posted February 18, 2020. The copyright holder for this preprint (which was not certified by peer review) is the author/funder. All rights reserved. No reuse allowed without permission.

\section{TOC art}

44

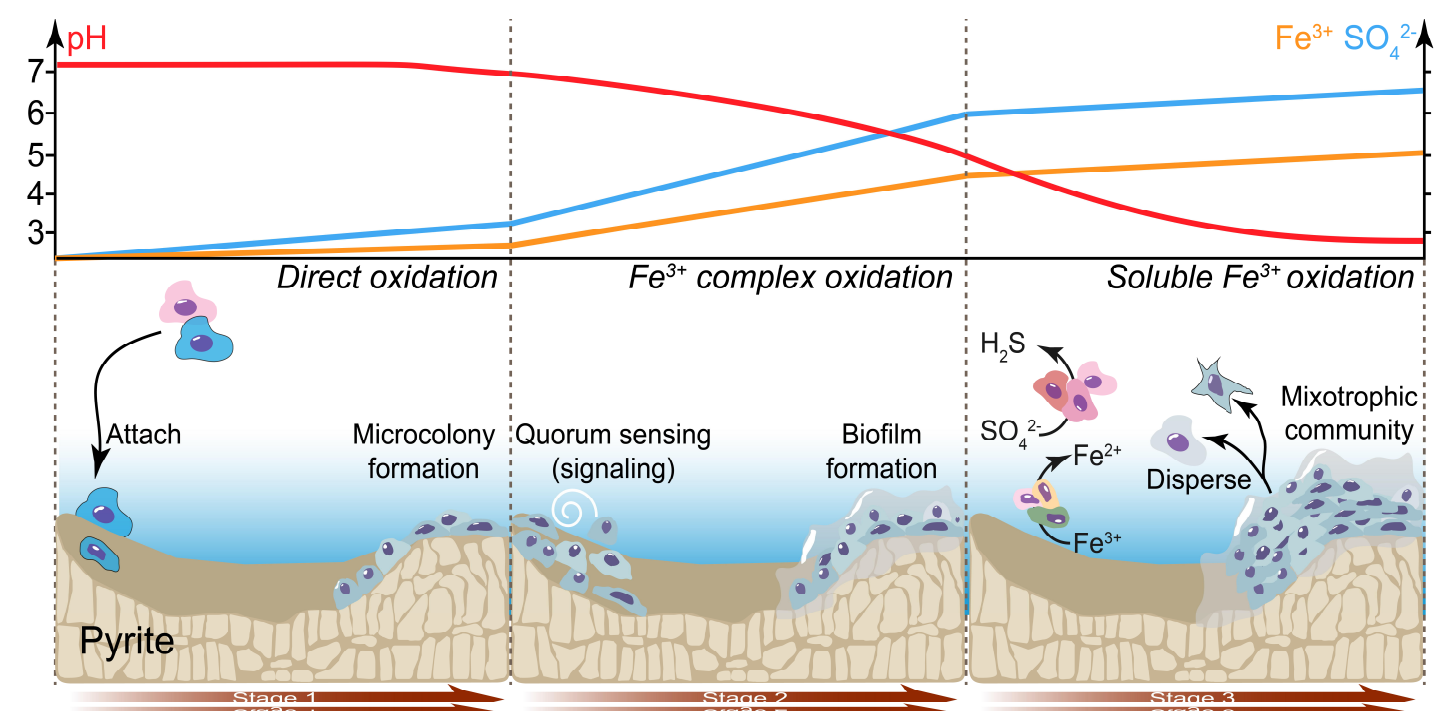

45 


\section{Introduction}

47 Pyrite $\left(\mathrm{FeS}_{2}\right)$ is by mass the most abundant thermodynamically stable iron-sulfide mineral in earth's crust ${ }^{1}$. Over geological times, its burial and weathering interreacted intensively with organic matter in sediments and oxygen in atmosphere ${ }^{2}$, thus played

50 a key role in the variation of earth's surface chemical system (e.g. the Canfield ocean ${ }^{3}$ )

51 and the evolution of life diversity ${ }^{4}$. For modern earth, despite the importance of pyrite oxidation on earth's element cycling, the transportation of contaminants and formation of acid mine drainage (AMD) are also strongly affected ${ }^{5}$. Microbial pyrite oxidation has been studied extensively under aerobic conditions with low $\mathrm{pH}$, typically in the context of AMD formation. Acidophilic microbes, represented by Acidithiobacillus ferrooxidans, prominently accelerates pyrite dissolution through aerobic soluble $\mathrm{Fe}^{2+}$ oxidation, which produces soluble $\mathrm{Fe}^{3+}$ as chemical oxidant for pyrite ${ }^{6,7}$. However, for most geological sites, such as soil, sediments, and shallow aquifers, anaerobic and buffered geochemical conditions, are more common than an aerobic environment with

60 low $\mathrm{pH}^{8}$.

61 The simultaneous nitrate reduction and sulfate production has been observed at multiple pyrite-bearing aquifers over the past few decades ${ }^{9,10}$. A series of field study suggested

63 that the coupling of microbial mediated chemolithotrophic denitrification and pyrite

64 oxidation contributed to the nitrate consumption, sulfate production ${ }^{9,11,12}$, release of 65 trace elements in pyrite lattice ${ }^{13,14}$, and stable isotope fractionation of ${ }^{15} \mathrm{~N},{ }^{18} \mathrm{O}$, and ${ }^{34} \mathrm{~S}$ 
67 (T.denitrificans) provided direct evidence of simultaneous nitrate reduction and ferric

68 and sulfate production ${ }^{17}$, where an electron balance considering the formation of $\mathrm{Fe}^{3+}$

69 and sulfate along with the transformation of nitrate to dinitrogen was in consistence

70 with the stoichiometry (Eq. 1).

$$
\mathrm{FeS}_{2(\mathrm{~s})}+3 \mathrm{NO}_{3(\mathrm{aq})}^{-}+2 \mathrm{H}_{2} \mathrm{O} \rightarrow \mathrm{Fe}(\mathrm{OH})_{3(\mathrm{~s})}+2 \mathrm{SO}_{4(\mathrm{aq})}^{2-}+1.5 \mathrm{~N}_{2(\mathrm{~g})}+\mathrm{H}_{(\mathrm{aq})}^{+} \quad \text { Eq. } 1
$$

72 Nevertheless, as an acid-non-soluble metal sulfides, pyrite derived all valance bands

73 from metal orbitals, leading its crystal substantial against proton promoted or direct

74 microbial dissolution ${ }^{18}$. Consequently, the role of functional microbes and the

75 mechanism of the chemical variations in pyrite-bearing aquifer are not clear ${ }^{19}$. In

76 addition, anaerobic pyrite oxidation process was recognized as promising method in

77 remediating nitrate contamination ${ }^{20-23}$. However, the circumneutral condition limited

78 pyrite oxidation process, resulting in low nitrate removal efficiency ${ }^{24-26}$. which in turn

79 called for fundamental mechanism studies.

80 On the other hand, research of pyrite oxidation under AMD-like conditions has dived

81 far into molecular and genetic level ${ }^{27}$. The utilization of state-of-art techniques, such

82 as corrosion electrochemistry and molecular biology, enables the understanding of the

83 mechanism and kinetics of this process from the mineralogy aspects ${ }^{18,28,29}$ and the

84 means of process acceleration by microbes ${ }^{30}$.. Two possible pathways drive the

85 anaerobic pyrite oxidation at neutral $\mathrm{pH}^{31}$. In the indirect pathway, pyrite is attacked

86 by chelated $\mathrm{Fe}^{3+}$, which requires either an acidic nano-environment or putative chelated

87 compounds, microbes therefore acquire energy through iron assisted electron-shuttling. 
88 Alternatively, pyrite may be oxidized via direct microbial attack along with the cell

89 colonization, which is postulated need the participation of putative cell compounds.

90 Although both pathways may explain the role of microbes, more experimental evidence

91 are required to validate the pathways exist or not and to determine which pathway

92 excavate more electrons from pyrite oxidation for microbes.

93 The goal of this research is to elucidate the mechanism of microbial mediated anaerobic

94 pyrite oxidation under neutral $\mathrm{pH}$ and to promote optimization of pyrite oxidation-

95 based pollution control in municipal plants or aquifers. We analyzed electrochemical

96 oxidation behavior using pyrite cubic electrode and conducted microbial experiments

97 with pyrite as sole substrate and nitrate as electron accepter to elucidate if

98 microorganisms can oxidize pyrite directly and which pathway dominated pyrite

99 oxidation. The results obtained not only enhances our understanding of the role microbe

100 plays while interreacting with solid pyrite, but also has potentially broad environmental

101 impacts and implications for major elements cycling from both geochemistry and

102 environmental remediation aspects.

\section{Results}

104 1. Redox potential limiting anaerobic microbial pyrite oxidation 

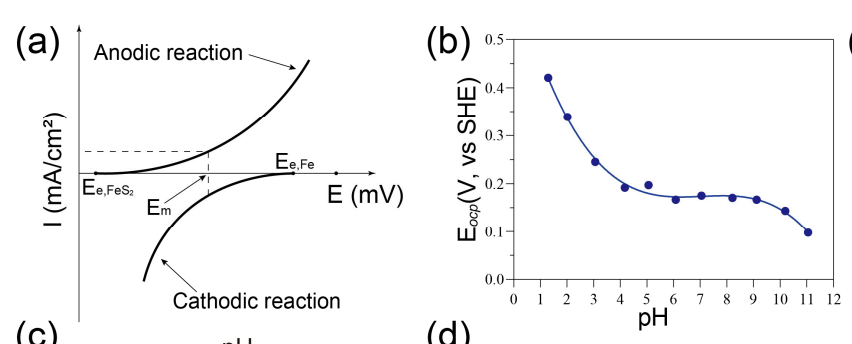

(e) Inorganic $\underset{--500-}{E(m V)}$ Organic

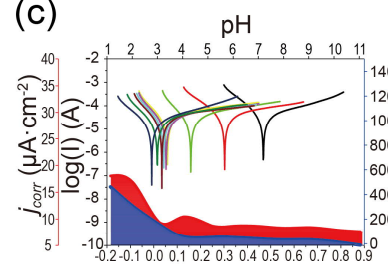

(d)

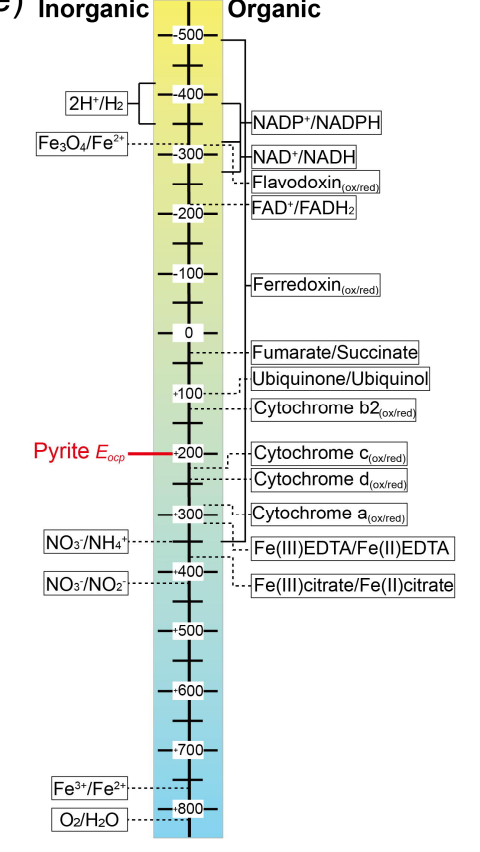

106
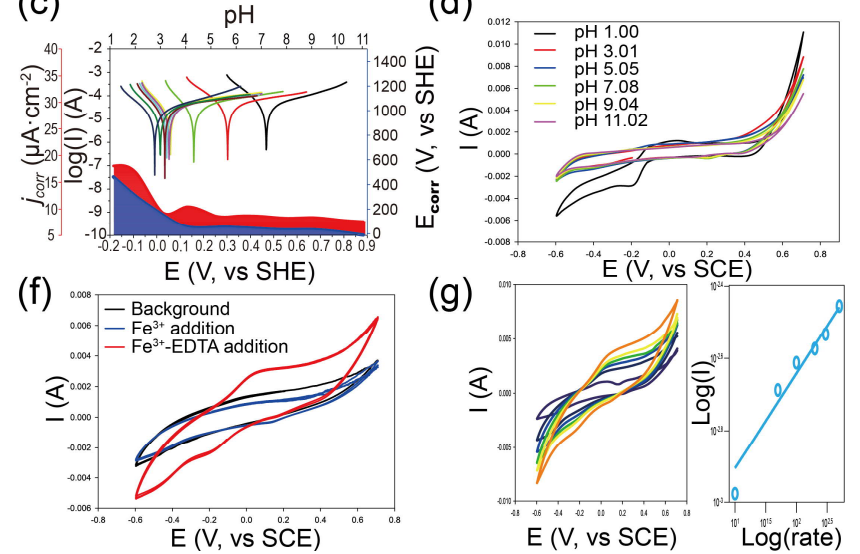

(g)

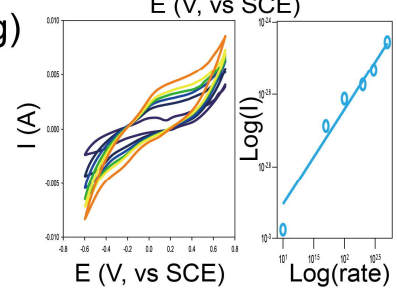

Figure 1 Electrochemical profile of anaerobic pyrite oxidation under neutral conditions using

107 lab-made pyrite cubic electrode. Schematic illustration of electrochemical mixed potential

108 theory (a), $\mathrm{E}_{\text {ocp }}$ variation in $0.1 \mathrm{M} \mathrm{Na}_{2} \mathrm{SO}_{4}$ solution with various $\mathrm{pH}(\mathrm{b})$, Tafel plot for pyrite

109 electrode in $0.1 \mathrm{M} \mathrm{Na}_{2} \mathrm{SO}_{4}$ solution with various $\mathrm{pH}$ (c), Cyclic voltammetry curves of pyrite

110 electrode in $0.1 \mathrm{M} \mathrm{Na}_{2} \mathrm{SO}_{4}$ solution with different $\mathrm{pH}$ (d), Redox potentials (vs. SHE) of

111 important redox reactions in electron transport chains in cell (Modified from ${ }^{32}$ ) (e), Cyclic

112 voltammetry curves of pyrite electrode in $0.1 \mathrm{M} \mathrm{Na}_{2} \mathrm{SO}_{4}$ solution $\left(\mathrm{pH}\right.$ 7.0) with $\mathrm{Fe}^{3+}$ or $\mathrm{Fe}^{3+}-$

113 EDTA addition (f), Successive cyclic voltammetry scans of pyrite electrode in $0.1 \mathrm{M} \mathrm{Na}_{2} \mathrm{SO}_{4}$

114 solution ( $\mathrm{pH}$ 7.0) with $\mathrm{Fe}^{3+}$-EDTA addition with increased scan speeds and log/log plot of

115 change in anodic peak currents vs. change in scan rate $(\mathrm{g})$.

117 Of the electrochemical mixed potential theory (Figure 1a), the mixed potential $\left(E_{m}\right)$

118 referred to the measured redox potential difference between anode and cathode, which 
119 was the energy pushed the electrochemical reaction. $\mathrm{E}_{\mathrm{m}}$ was also equal to open circuit

120 potential $\left(\mathrm{E}_{\mathrm{ocp}}\right)$ that no redox reaction happens between electrodes and redox active

121 species in solution. Eocp analysis of pyrite electrode showed an intense decline from

1220.42 to $0.10 \mathrm{~V}$ (vs. standard hydrogen electrode (SHE)) with the increase of electrolyte

$123 \mathrm{pH}$ from 1 to 11 , and $\mathrm{E}_{\mathrm{ocp}}$ altered little within the $\mathrm{pH}$ range of 5-9 (Figure 1b). Similarly,

124 linear sweep voltammetry evaluation showed decreased pyrite electrode stability with

125 electrolyte accretion (Figure 1c), the asymmetric curves of Tafel plots (Figure 1c) also

126 suggested that the pyrite electrode was oxidized irreversibly.

127 When cyclic voltammetry (CV) was performed in anaerobic electrolyte, the change of

128 electrolyte $\mathrm{pH}$ did not alter the reactivity of pyrite electrode (Figure 1d). Because

129 soluble $\mathrm{Fe}^{3+}$ only presented in $\mathrm{pH} 1$ condition, its reduction to $\mathrm{Fe}^{2+}$ on pyrite surface

130 was verified with the significant catholic peak observed (Figure 1d). Based on the $\mathrm{E}_{\text {ocp }}$

131 data, which was confirmed by linear sweep and cyclic voltammetry, a redox potential

132 ladder under physiological $\mathrm{pH}$ (Figure 1e) was constructed from previous data ${ }^{32} \cdot \mathrm{Fe}^{3+}-$

133 EDTA was able to oxidize pyrite under neutral $\mathrm{pH}$ (Figure 1e), which was tested by CV

134 scan with $\mathrm{Fe}^{3+}$ or $\mathrm{Fe}^{3+}$-EDTA added in $\mathrm{pH} 7$ electrolyte. We observed significant anodic

135 and catholic peaks (Figure 1f) when adding $\mathrm{Fe}^{3+}$-EDTA, indicting $\mathrm{Fe}^{3+}$-EDTA can

136 oxidize pyrite under neutral $\mathrm{pH}$, while $\mathrm{Fe}^{3+}$ not. To distinguish whether diffusion or

137 adsorption was the rate-limiting step of redox active molecules' (i.e. $\mathrm{Fe}^{3+}$-EDTA)

138 reactions on electrode surface, we increased the CV scan rate gradually from 10 to 2,000

$139 \mathrm{mV} / \mathrm{s}$ (Figure 1g), and an increase in peak current was observed. Molecules may be 
140 oxidized/reduced on the electrode surface by diffusion or adsorption controlled

141 mechanisms ${ }^{33}$, which can be distinguished by successive CV scan with gradually

142 increased scan rate ${ }^{34}$. Given current rise was proportional to the square root of the scan

143 speed in diffusion-controlled process ${ }^{35}$, a diffusion-controlled mechanism was

144 confirmed in the case of $\mathrm{Fe}^{3+}$-EDTA on pyrite surfaces, in which a slope of 0.26 with

$145 R^{2}=0.971$ was obtained by plotting a $\log (\mathrm{I})$ (where $\mathrm{I}$ is the anodic peak current) against

$146 \log ($ rate $)$ (where rate is the scan rate in $\mathrm{mV} / \mathrm{s}$ ) (Figure $1 \mathrm{~g}$ ).

\section{Accelerated anaerobic microbial pyrite oxidation by EDTA addition}

(a)
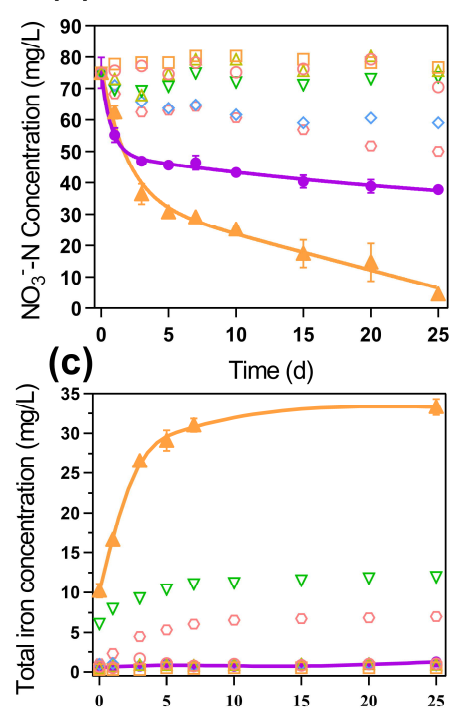

(e)

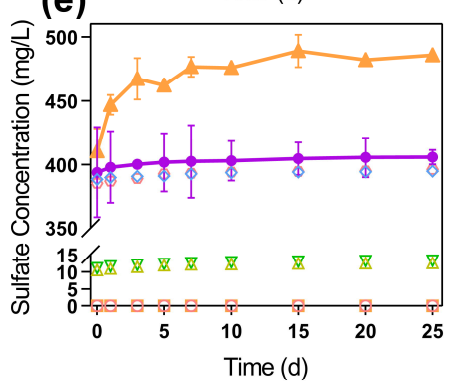

(b)
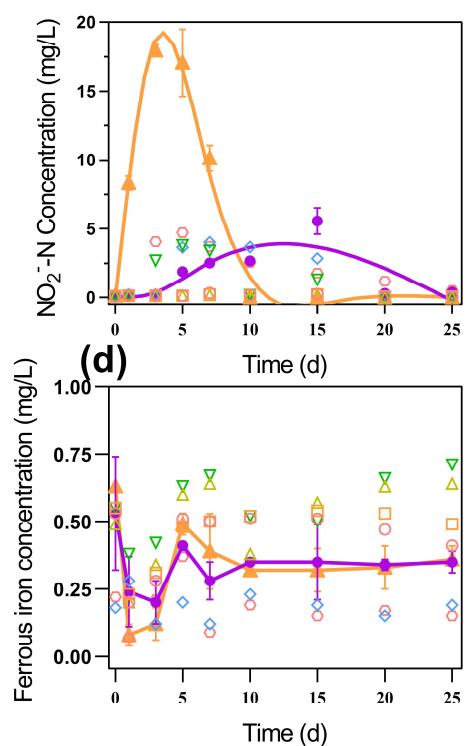

$\rightarrow$ Ctrl (mos+pyrite)

$\operatorname{Rec}($ mos+pyrite+EDTA)

Mos (mos alone)

mos+EDTA

Blank (medium alone)

EDTA alone

pyrite alone

pyrite+EDTA

149 Figure 2 Changes in aqueous species concentrations during microbial mediated anaerobic pyrite 
151 (e) concentration variation under experimental conditions with/without EDTA-addition and

152 microorganisms (mos) inoculation.

153

154 Without any lag period, nitrate concentration in experiments with pyrite and

155 microorganisms decreased rapidly in the first 3 days after inoculation, and the decrease

156 rate slowed down thereafter (Figure 2a). However, significantly faster nitrate removal

157 rate was observed in experiments with EDTA addition ( $\operatorname{Rec}, p=0.0078)$, nearly

158 complete nitrate removal was achieved within 25 days, while only half nitrate was

159 removed without EDTA addition (Ctrl). Similarly, nitrate reduction rates for treatments

160 without inoculum or growth substrate (i.e. pyrite) was much smaller than EDTA

161 amended microcosm set. Correspondingly, nitrite accumulation rate was much higher

162 than the Ctrl. The peak nitrite concentrations of Rec reached $18 \mathrm{mg}-\mathrm{N} / \mathrm{L}$ on day 4, while

163 the peak nitrite concentration of Ctrl did not show up until day 15 ( $6 \mathrm{mg}-\mathrm{N} / \mathrm{L})$..

164 Ammonia was not detected in all treatments. Total iron concentration in Rec had a

165 similar trend as nitrate, of which the concentration increased rapidly to ca. $30 \mathrm{mg} / \mathrm{L}$ in

166 the first 5 days, and kept a slow increment thereafter (Figure 2c). Obvious augment of

167 total iron was observed only in Rec (Figure 2c), while for other treatments, the total

168 iron concentrations were below $2 \mathrm{mg} / \mathrm{L}$.. In addition, ferrous iron concentrations in all

169 treatments were always lower than $1 \mathrm{mg} / \mathrm{L}$ in all experiments (Figure $2 \mathrm{~d}$ ), indicating

170 ferric iron was the major iron specie. 
171 Despite trace amount of reduced sulfur compounds from inoculum, pyrite was regarded

172 as the major electron donor for microbes. After 25 days of experiment, the increment

173 of sulfate concentration was $12.04,73.96,6.91$, and $2.13 \mathrm{mg} / \mathrm{L}$ for Ctrl, Rec, Mos, and

174 abiotic control, respectively (Figure 2e). Only a little sulfate was produced in abiotic

175 control, therefor it was confirmed the abiotic pyrite oxidation process can be neglected.

176 Theoretical mass ratio $(\mathrm{w} / \mathrm{w})$ of the produced sulfate and consumed nitrate was

177 calculated to be 1.03 based on Eq. 1. The actual mass ratio for Rec and Ctrl was 1.07

178 and 0.32 , respectively. While a small mass ratio deviation was found for Rec (3.9\%),

179 mass ratio for Ctrl varied a lot $(68.9 \%)$. The mass ratio deviation for Ctrl was ascribed

180 to the cooccurrence of autotrophic process using pyrite as electron donor and

181 heterotrophic process with necromass as electron source under low-energy-supply

182 conditions (Figure 2a), since the heterotrophic process could compete with autotrophic

183 process for electron accepter (i.e. nitrate). Compared with high sulfate background

184 concentration, a low sulfate concentration produced in Ctrl may also hinder the mass

185 ratio calculation.

186 3. Microbes tend to gather onto pyrite surface 
(a) $\begin{array}{lllll}0 & 20 & 40 & 60 & \\ \text { Value }\end{array}$

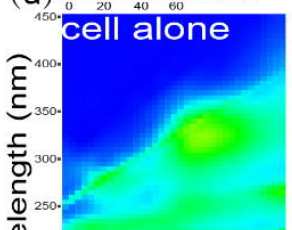

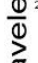

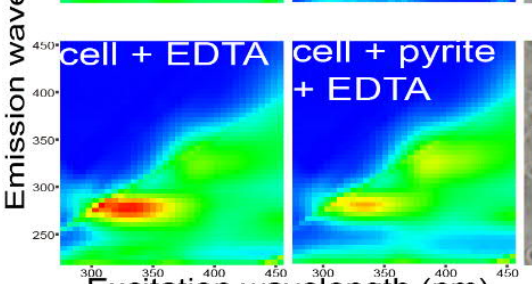

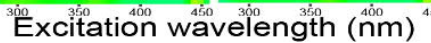

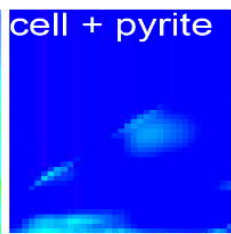

(b)

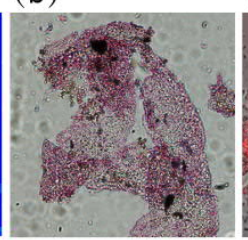

(c)

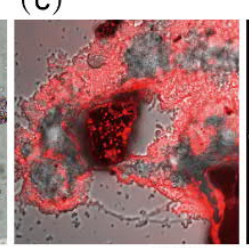

Without EDTA

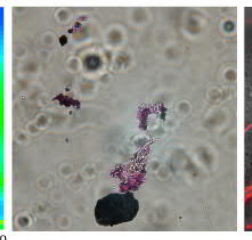

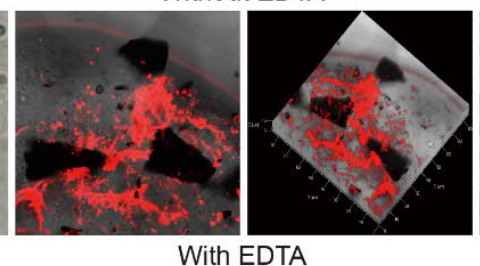

With EDTA (d)
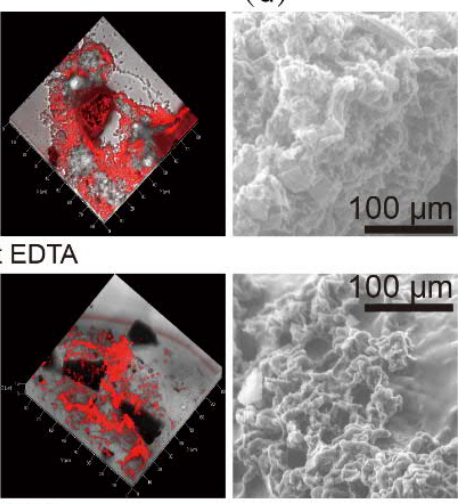

188 Figure 3 Microbial cultures tend to associate with pyrite surfaces. 3D-EEM spectra of the

medium supernatant after ca. 10 days of growth (a). DiI cell membrane stain (red) and

fluorescence images of the microbial cultures (b). DiI cell membrane stain and CLSM images

191 of the cell-mineral association from parallel microbial cultures after ca. 10 days of growth (c).

192 ESEM images of the cell-mineral association at same magnification (d).

193

194 The living state (i.e. planktonic or biofilm) of microbes has a strong impact on their

195 interactive relationship with pyrite, thus the supernatant of microbial culture and the

196 cell-mineral association were assayed. 3D-EEM (three-dimension excitation emission

197 matrix) of the supernatant from cell + pyrite cultures showed the lowest fluorescence

198 intensity (Figure 3a, Figure S4), implying potential microbial accumulation near pyrite

199 particles. Meanwhile, EDTA addition suppressed biofilm formation ${ }^{36}$, leading to a

200 multiplied cell number in cultures with EDTA (Figure 3a, Figure S3). The microbial

201 accumulation near pyrite and on pyrite surface were further verified using fluorescence

202 microscopy, CLSM (confocal laser scanning microscope), and ESEM (environmental

203 scanning electron microscope) (Figure 3b-d). In cultures without EDTA, microbes 

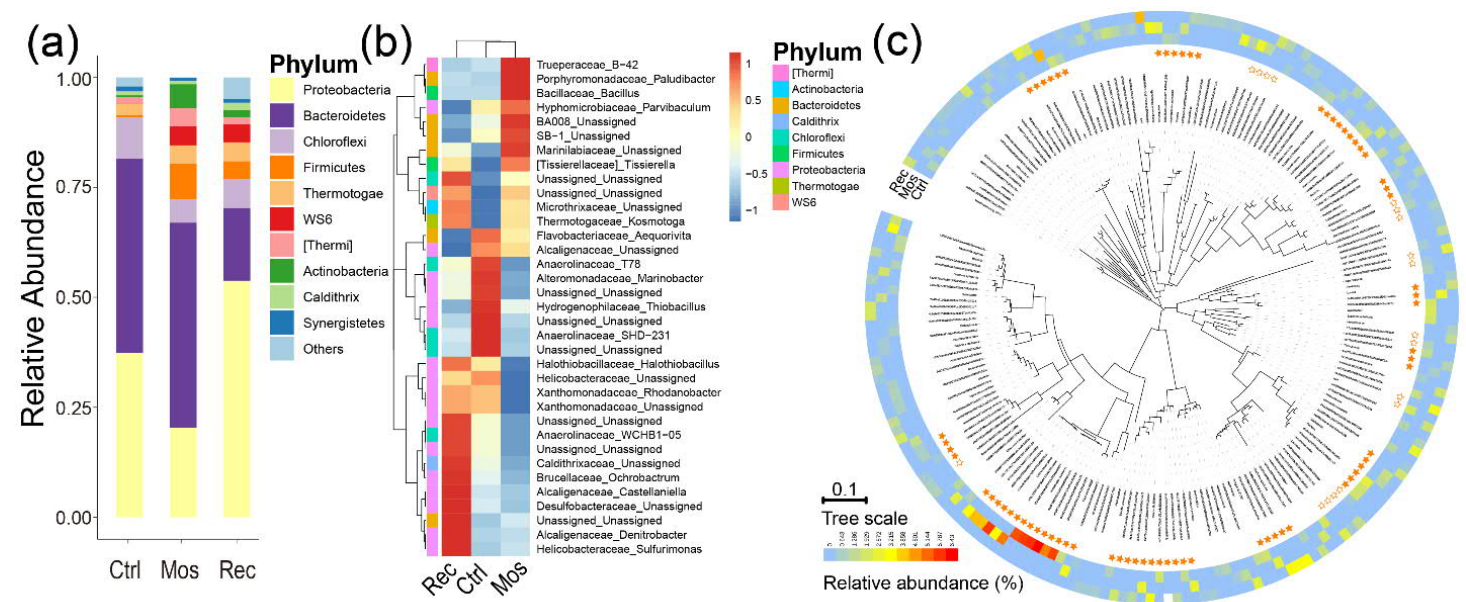

209 Figure 4 Microbial community structure based on 16S rRNA gene amplicon sequences. The

top 35 genera (b). Phylogeny, abundance, and core microbiome of bacterial ASVs in the 3

213 https://itol.embl.de/tree/602475147460471565937282).

215 The taxonomic composition of microbial cultures based on amplicon sequencing

216 showed that microbial communities were dominated by phylum Bacteroidetes and

217 Proteobacteria with lower abundance in microbial cultures without EDTA (Figure 4a).

218 However, phylum Proteobacteria got more dominative in cultures with EDTA addition

219 (Figure 4a). At genus level (Figure 4b, Figure S12), sulfur and nitrogen cycles related genera (Sulfurimonas, Denitrobacter, and an unassigned genus from family 
221 Desulfobacteraceae) showed a relatively higher abundance in EDTA-addition culture,

222 while in EDTA-free culture the high abundance genera switched to Marinobactor and

223 Thiobacillus (Figure 4b). Furthermore, genera B-42, Paludbacter, and Bacillus tend to

224 govern the starved culture (Mos).

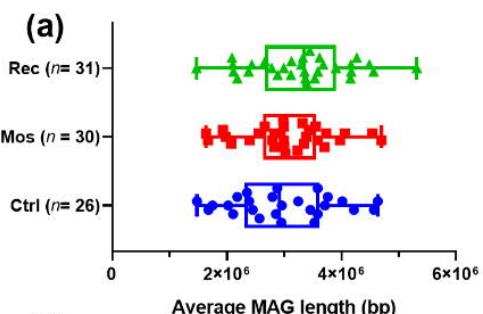

(d)

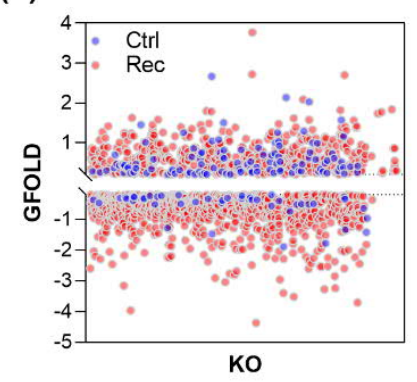

(b)

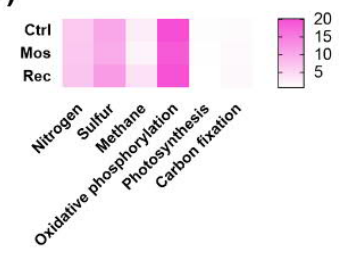

(e)

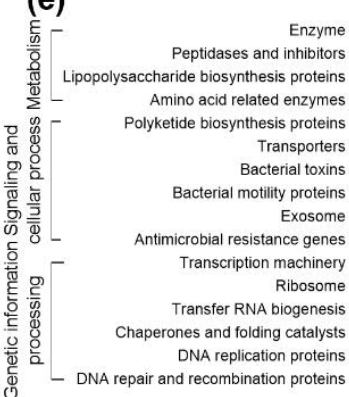

(c)

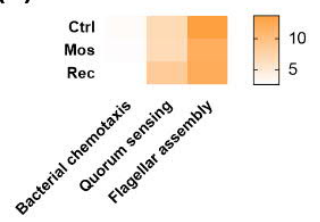

(f)

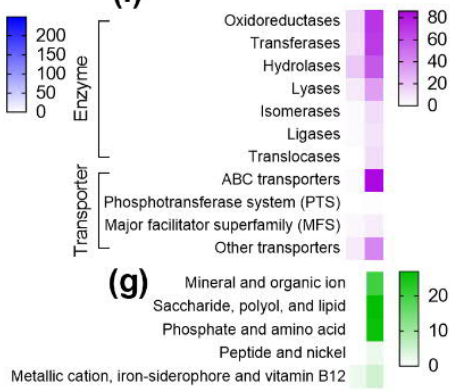

227 Figure 5 Functional structure based on metagenomic sequencing. MAGs from cultures without

228 EDTA addition had smaller MAG length (a). EDTA-addition cultures had higher abundance of

229 energy metabolism genes, legend (genes/genome) (b). Cellular community and mobility related

230 genes increased with more energy available, legend (genes/genome) (c). Compared with

231 EDTA-free cultures, EDTA addition cultures had more discrepant genes, indicating an

232 oligotrophic state of EDTA-free cultures (d). Based on KEGG protein family analysis, high

233 abundance genes of Rec cultures mainly involved those encoding enzymes and transporters (e).

234 High abundance enzyme encoding genes of Ctrl and Rec culture were of different kinds and

235 abundance, and Rec culture had the most abundant of ABC transporters encoding genes (f). 
236 Within $\mathrm{ABC}$ transporters encoding genes, organic compounds transportation related genes were

237 of high abundance in Rec culture, while high abundance genes in Ctrl cultures involved mainly

238 in metallic, cation, iron-siderophore, and vitamin B12 transportation (g).

240 Taxonomic binning of the 3 metagenomes yielded 87 high quality (genomic

241 completeness higher than $90 \%$ and contamination lower than 5\%) metagenomic

242 assembled genomes (MAG) (Figure 5a). MAGs recovered from Rec had larger genome

243 size (Figure 5a), which indicated a higher evolution complexity and functional

244 redundancy ${ }^{37}$. The MAGs obtained were then annotated with eggNOG database ${ }^{38}$ and

245 the genes were mapped to KEGG database ${ }^{39}$. The abundance of genes involved in

246 major energy metabolism pathways showed that MAGs from Rec had the highest

247 abundance of energy metabolism genes in every sub-pathway (Figure 5b). Genes

248 related to cellular community and mobility demonstrated that more genes in Ctrl MAGs

249 involved in bacterial chemotaxis and flagellar assembly process (Figure 5c), which

250 suggested potential cell movement towards solid substrate (i.e. pyrite). While Rec

251 MAGs had the highest abundance of quorum sensing encoding genes (Figure 5c), which

252 suggested a more complexed microbial community.

253 To evaluate the functional difference between cultures Rec and Ctrl, the differential

254 abundance of the annotated genes from these two metagenomes were calculated using

255 Mos metagenome as reference (Figure 5d). Under a differential threshold of 0.2

256 GFOLD, more genes with higher abundance were found from Rec metagenome (Figure 
257 5d), implying an immense functional diversity. While the minor difference between Ctrl

258 and Mos metagenomes (Figure 5d) indicated their similarity in metabolic potential. The

259 high abundance differential genes were further analyzed with KEGG protein family

260 (Figure 5e), which showed, in both Ctrl and Rec metagenomes, genes encoding

261 enzymes and transporters were of higher abundance, and the gene abundance of Rec

262 are higher than Ctrl. Among the enzyme encoding genes, only hydrolases were of high

263 abundance in Ctrl, while Rec had several high abundance enzymes (Figure 5f).

264 Meanwhile, ABC transporters encoding genes of Rec were of the highest abundance

265 (Figure 5f). It was noteworthy that several organic compounds transportation (such as

266 saccharide, lipid, and amino acids) related ABC transporters were of high abundance in

267 Rec, while only genes involved in metallic, cation, iron-siderophore, and vitamin B12

268 transportation were of high abundance in Ctrl (Figure 5g). From the numbers of

269 differential genes (Figure 5d) and the similar abundance pattern across different levels

270 of protein families (Figure 5e-g), genes from Rec were always of higher abundance in

271 more functional categories. Thus it was concluded that the microbial community in Rec

272 culture was of higher functional diversity and redundancy.

273 Discussions

274 1. Microbes could oxidize pyrite by either cellular compounds directly or $\mathbf{F e}^{3+}$ -

275 complex

276 The $\mathrm{E}_{\text {ocp }}$ of pyrite electrode was examined to decrease with the $\mathrm{pH}$ increment under

277 anaerobic conditions (Figure 1b), which was in analogous to that observed in aerobic 
278 basic $^{40}$ and acidic situations ${ }^{41}$. Since the rate-limiting step of aerobic pyrite oxidation

279 was the electron transfer from pyrite bulk crystal to surface adsorbed $\mathrm{O}_{2}$ molecular, the

280 decreased $E_{\text {ocp }}$ was attributed to reduced obstacle of electron transfer ${ }^{42}$. The measured

$281 \mathrm{E}_{\text {ocp }}$ was ca. $0.2 \mathrm{~V}$ at pH 7.0 (Figure 1b), which was higher than that from literature (ca.

$282-0.28 \mathrm{~V})^{43}$. However, the $\mathrm{E}_{\mathrm{ocp}}$ that Tao et al. ${ }^{43}$ obtained varied a lot among different

283 samples, and discrepant electrode preparation methods and electrolyte may also arise

284 this issue. Even though the measured $\mathrm{E}_{\text {ocp }}$ value varied, its tendency was reliable, and

285 was also validated by the corrosion current decline in Tafel assay (Figure 1c). Under

286 aerobic acidic situations, pyrite $\mathrm{E}_{\text {ocp }}$ was reported to be ca. $0.6 \mathrm{~V}^{44,45}$, and pyrite

287 oxidation can merely happen under redox potential of $0.65 \mathrm{~V}^{46}$. It can therefore be

288 concluded that $E_{\text {ocp }}$ was a key discrepancy between acidic and basic cases. Furthermore,

$289 \mathrm{CV}$ analysis did not show obvious pyrite oxidation at $\mathrm{pH}$ above 2.0 (Figure 1d), while

290 unambiguous oxidation occurred at $\mathrm{pH}$ 2.0. Pyrite oxidation at $\mathrm{pH} 2.0$ was in

291 consistence with previous study ${ }^{45}$, and can be interpreted with the enhanced solubility

292 of $\mathrm{Fe}^{3+}$.

293 To demonstrate the relationship between pyrite $\mathrm{E}_{\mathrm{ocp}}$ and microbial mediated redox

294 reactions under circumneutral conditions, the pyrite $E_{o c p}$, redox potentials of common

295 chemical reaction, and potentials of important cellular redox reactions were

296 summarized into a ladder plot (Figure 1e). Many cellular compounds were then able to

297 oxidize pyrite directly thermodynamically, which was of immense disparity with the

298 fact that pyrite cannot be oxidized directly by cellular compounds under acidic 
299 conditions ${ }^{46}$. Previous study showed there were reversible redox reactions between

300 pyrite and hydroquinone molecules ${ }^{33}$, which was in agreement with direct pyrite

301 oxidation (Figure 1e). Considering the rate-limiting step in hydroquinone and pyrite

302 interaction was hydroquinone diffusion rather than interfacial electron transfer ${ }^{33}$, the

303 direct pyrite oxidation by cell components was further supported. For the direct and

304 indirect pathways of anaerobic pyrite oxidation under circumneutral $\mathrm{pH}^{31}$, it was not

305 reasonable for microbes maintaining an acidic microenvironment. Because the pyrite

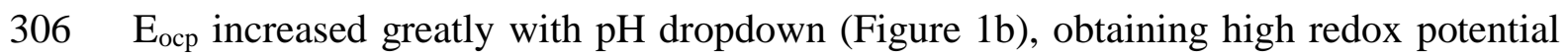

307 compounds with acidic environments was not energy efficient for microbes. On the

308 other hand, high redox potentials can be easily obtained with ligands like EDTA or

309 citrate (Figure 1e), thus making the indirect pathway much convincing. To validate

310 indirect pyrite oxidation, CV assay was carried out with EDTA addition, and we

311 observed significant pyrite oxidation (Figure 1f). The $\mathrm{Fe}^{3+}$-EDTA complex diffusion

312 limited the overall reaction indicated a fast surface electron transfer (Figure 1g), which

313 may further support the hypothesis that microbes accelerated pyrite oxidation by

314 producing ligands.

315 Respecting microbes may produce ligands to accelerate pyrite oxidation, it was

316 reasonable to hypothesis that pyrite oxidation can be strengthened by adding ligands.

317 By adding EDTA, pyrite oxidation was enhanced significantly from 0.019 to $0.092 \mathrm{~d}^{-1}$

318 (Figure 2). The pyrite dosage normalized pseudo-first order kinetics $(0.009 \mathrm{~L} /(\mathrm{g} \cdot \mathrm{d}))$

319 was also near 2 times greater as that $(0.005 \mathrm{~L} /(\mathrm{g} \cdot \mathrm{d}))$ of previous study in our laboratory 
320 using similar inoculum ${ }^{20}$. The nitrate decline observed in starved culture (Mos) can be

321 ascribed to the heterotrophic denitrification process using organics from cell lysis ${ }^{47,48}$.

322 Rapid nitrate removal in the first 3 days was explained by the existence of reduced

323 sulfur compounds on pyrite surface ${ }^{49}$, which was in agreement with previous study

324 using Thiobacillus thioparus (a bacterium that can only oxidize sulfur compounds) that

325 nitrate removal was only observed in the first few days ${ }^{47}$, this was also supported by

326 the fact that acid-pretreated pyrite particles had lower reaction rate $\left(0.004 \mathrm{~L} /(\mathrm{g} \cdot \mathrm{d})^{20}\right.$,

$\left.3270.0004 \mathrm{~L} /(\mathrm{g} \cdot \mathrm{d})^{50}\right)$. Nitrite accumulation was usually observed in anaerobic pyrite

328 oxidation process ${ }^{17,20,50}$ and was considered as the major intermediate product ${ }^{17,48}$,

329 which was attributed to the inhabitation of nitrate on nitrite reductase ${ }^{51}$ and the fact

330 that nitrate was more preferred electron accepter than nitrite ${ }^{52}$. Nitrite accumulation

331 occurred in both cultures that with/without EDTA addition ( Figure 2b), while the earlier

332 nitrite accumulation peak occurred along with the faster the denitrification rate. Apart

333 from faster nitrite accumulation, higher nitrite concentration was also perceived in Rec

334 than that in Ctrl, which was ascribed to the more nitrate been reduced in Rec. It was

335 noteworthy that even though nitrite accumulation occurred much earlier and intenser in

336 Rec, of which the nitrite concentration also decreased much faster, which was resulted

337 from the nitrate concentration decline and enough electron supply by help of EDTA.

\section{2. Biogeochemical model of anaerobic microbial pyrite oxidation}




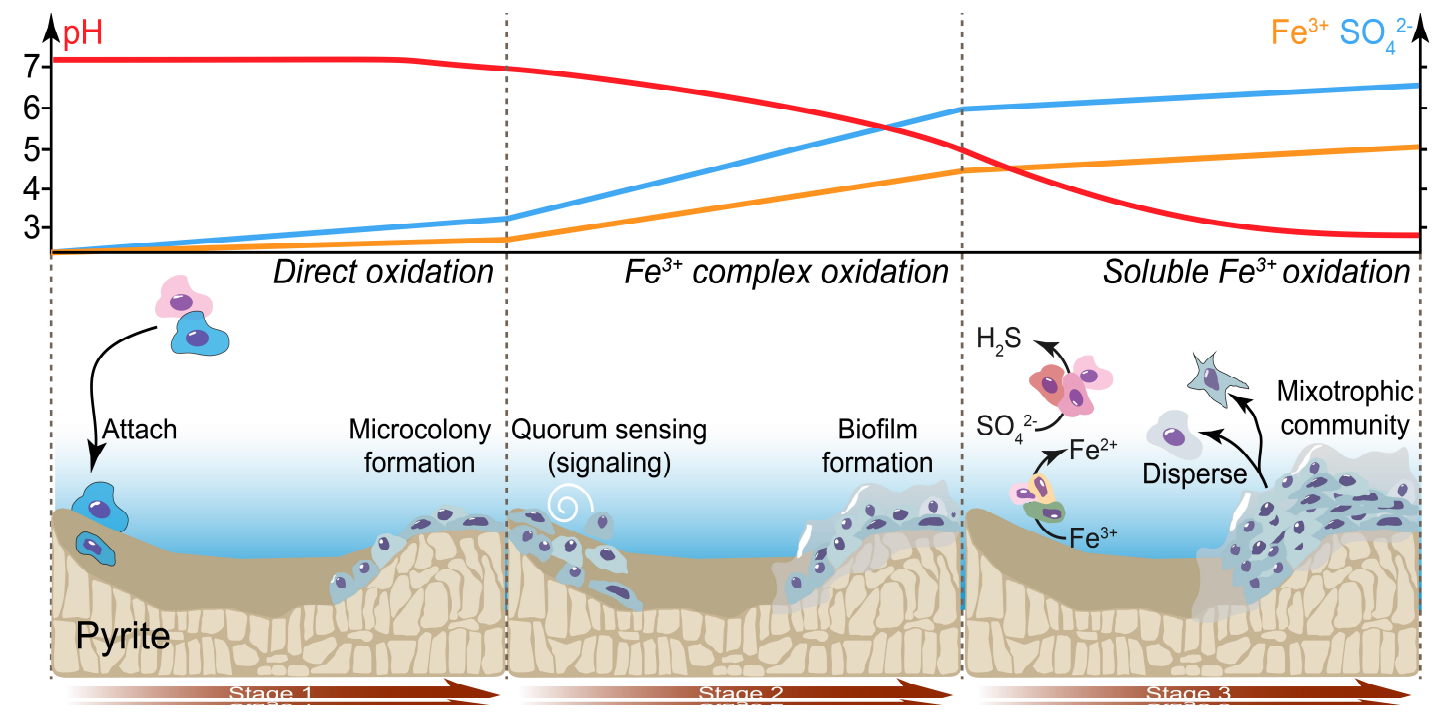

Figure 6 Concept model of anaerobic pyrite oxidation process.

342 Combining experimental results and previous studies, a conceptional biogeochemical

343 model of anaerobic microbial pyrite oxidation was proposed (Figure 6), which may

344 provide insights into the couplings of geochemistry, mineralogy, and microbial

345 dynamics within this process. Three main stages were included in the conceptional

346 model, the first stage came the period that microbes colonized at pyrite surface and tend

347 to form localized colonies, during which pyrite was oxidized mainly by direct microbial

348 attack; once simple biofilm formed on pyrite surface, the microbes produced ligands

349 can help pyrite oxidation by chelating with $\mathrm{Fe}^{3+}$; finally came complex microbial

350 communities on pyrite surface, and oxidation occurred mainly by soluble $\mathrm{Fe}^{3+}$ within

351 acidic micro niche.

352 Redox potential is a key factor influencing the initial pyrite oxidation at the first stage.

353 The pyrite oxidation under anaerobic circumneutral conditions can be achieved with

354 potential higher than $200 \mathrm{mV}$ (Figure 1b), which differed from that needed under 
355 aerobic conditions $(650 \mathrm{mV}){ }^{46}$. Thus cellular components with high redox potential

356 could oxidize pyrite by direct attack (Figure 1b). Owing to the deficient energy supply,

357 the energy metabolism was insufficient for ligands production, and inadequate to

358 uphold indirect pyrite oxidation pathway. Considering $\mathrm{Fe}^{3+}$ tended to precipitate under

359 neutral $\mathrm{pH}$, pyrite oxidation may proceed in direct pathway (Figure 3), which was

360 supported by the fact that microbes tended to form biofilm on pyrite surface ${ }^{53}$ and

361 direct cell attachment was always required for pyrite oxidation ${ }^{54}$. In addition, initial

362 pyrite oxidation happened by surface $\mathrm{Fe}^{2+}$ oxidation rather than sulfur oxidation ${ }^{28}$.

363 Even though sulfur could supply more electrons than $\mathrm{Fe}^{2+}$, iron oxidizing microbes may

364 prevail rather than sulfur oxidizing ones. Specifically, for T.denitrificans (an iron and

365 sulfur oxidizing bacterium) and Sulfurimonas denitrificans (S.denitrificans, a sulfur

366 oxidizing bacterium), a higher abundance for T.denitrificans in EDTA-addition culture

367 and for S.denitrificans in EDTA-free culture were therefore reasonable (Figure 4b),

368 which was in consistent with previous column study using different ratio of pyrite and

369 sulfur ${ }^{55}$. While Acidovorax sp. BoFeN1 (an iron oxidizing bacterium that cannot

370 oxidize sulfur) was proved cannot mediating pyrite oxidation ${ }^{49}$, possible explanation

371 was that, without using sulfur released from pyrite oxidation, electrons from $\mathrm{Fe}^{2+}$

372 oxidation were too few to support cell proliferation.

373 Along with direct pyrite oxidation by high redox potential cellular compounds, reduced

374 sulfur components that released from pyrite crystal were utilized by microbes and

375 biofilm evolved on pyrite surface ${ }^{53}$, and then simple microbial communities developed 
$376{ }^{56}$, which was a milestone indicating the second reaction stage. In cultures adding EDTA,

377 high diversity of energy metabolism was observed (Figure 5b), and was confirmed by

378 determination of electron transport system activity (ETSA, Figure S6), reactive oxygen

379 species (ROS, Figure S5), and cytochrome C (Figure S7), which can be attributed to

380 the energy supply increment by utilizing the released reduced sulfur. Microbes with

381 vigorous metabolism had high abundance of transport protein (Figure 5e, g), which was

382 also confirmed in 3D-EEM analysis (Figure 3a). Meanwhile, limited pyrite surface area

383 hindered the ever-increasing cell-mineral attachment (Figure 3c, d), thus microbes may

384 use $\mathrm{Fe}^{3+}$ complex with produced ligands as pyrite oxidants preferably in the local

385 reaction region formed by biofilm ${ }^{57}$. The real process can be similar with cultures

386 adding trace EDTA, within which observed significant pyrite oxidation enhancement

387 (Figure S2). Furthermore, considering the rapid increase of pyrite $\mathrm{E}_{\mathrm{ocp}}$ with $\mathrm{pH}$ drop

388 (Figure 1b), it was not likely for microbes to maintain an acidic microenvironment

389 during this period. It should be noted, owing to the readily available reduced sulfur on

390 pyrite surface ${ }^{49}$, experiments using crushed pyrite particles may switched into stage 2

391 shortly, leading to a fast reaction rate initially (Figure 2); on the contrary, pretreatment

392 removing surface oxide layer may result in a reduced reaction rate and sulfate

393 concentration ${ }^{20,50,58}$, which was an indication for stage 1.

394 As a result of continuous pyrite oxidation, physicochemical properties of the cell-pyrite

395 surface changed. Key parameters including nitrate, sulfate, and pH may show decrease,

396 increase, and drop tendency, respectively, which can be ascribed to the nitrate 
397 consumption and sulfate production mediated by cellular metabolism. Corresponding

398 to physicochemical variation, the surface microbiomes changed with two major

399 attributes, i.e. the strengthened biomass production powered by enough energy supply,

400 and microbial functional differentiation drove by discrepant environmental factors. For

401 cultures adding EDTA, high level phylogenetic diversity (Figure 4b) and functional

402 diversity (Figure 5) was observed on account of sufficient electron supply. In analogue

403 to this stage, in the later period of aerobic pyrite oxidation, the abundance of sulfate

404 reducing bacteria (SRB) that use organics from autotrophic bacterium's permeation or

405 lysis as carbon source increased ${ }^{59}$, indicating an ascended community diversity. Since

406 efficient pyrite oxidation can be hardly completed with $\mathrm{Fe}^{3+}$ complex (Figure 1b, e),

407 using soluble $\mathrm{Fe}^{3+}$ as oxidant may be preferable for microbes under acidic environment,

408 namely the micro-environment would switch from neutral to acidic.

\section{4. Environmental implications}

410 Microbial mediated anaerobic pyrite oxidation has important implications for

411 geochemistry on modern earth. For pyrite bearing sediments and shallow aquifers, the

412 penetration of nitrate from various sources may initiate anaerobic pyrite weathering ${ }^{17}$.

413 Traditionally, a direct chemical reaction between nitrate and pyrite was not expected to

414 occur or examined as very slow kinetics ${ }^{60}$. Even though the formed nitrite from nitrate

415 radiolysis was capable oxidizing pyrite chemically ${ }^{19}$, its impact was limited because of

416 the slow reaction kinetics ${ }^{61}$. However, taking fact that the electrochemical oxidation

417 threshold of pyrite at circumneutral conditions (ca. $200 \mathrm{mV}$, Figure 1b) was much lower 
418 than the pre-assumed value (ca. $650 \mathrm{mV},{ }^{46}$ ), the potential rates and impacts of pyrite

419 oxidation at initially neutral-pH systems should be reexamined, and the importance of

420 microbes should be emphasized since either high redox potential cell compounds or

421 produced organic ligands do accelerate pyrite oxidation. With microbial mediated pyrite

422 oxidation caused by nitrate plume leaching, the mobility of redox-sensitive

423 radionuclides ( $\operatorname{such}$ as $\mathrm{Se}, \mathrm{Tc}, \mathrm{U}, \mathrm{Np}$, and $\mathrm{Pu}$ ) ${ }^{62}$, as well as toxic metals ${ }^{63}$, may increase,

424 and thereby threaten the eco-security.

425 Microbial mediated anaerobic pyrite oxidation could also play a role in pollution

426 control, including nitrate contamination attenuation in groundwater, advanced nutrients

427 removal in municipal plants, and mobilization of toxic metals ${ }^{20,23,50}$. Even though prior

428 studies has focused on nutrients removal in artificial wetlands with pyrite ${ }^{24}, \mathrm{pH}$ drop-

429 down in pyrite-based denitrification column ${ }^{26}$, and immobilization of toxic metals

430 using particular pyrite ${ }^{64}$, a lack of fundamental understanding of how anaerobic pyrite

431 oxidation occurred has hindered further optimization for most systems. With the

432 provided electrochemical oxidation threshold (Figure 1) and concept model considering

433 different oxidation stages (Figure 6), further guidance for anaerobic pyrite oxidation-

434 based pollutant removal processes was expected.

435 Furthermore, subglacial microbial community driven by anaerobic pyrite oxidation has

436 been confirmed by meta-transcriptomics ${ }^{65}$ and sulfur isotope data ${ }^{66}$, and the existence

437 of active subglacial sulfur metabolism and its possible acceleration for pyrite

438 weathering has been suggested in pyrite bearing sites ${ }^{67}$. Thus, the concept model 
439 proposed here may provide helpful insights into how subglacial microbial community

440 sustained and evolved with a little energy available during glacial-interglacial cycles.

\section{Materials and methods}

442 Electrochemical analysis of pyrite oxidation under anaerobic circumneutral conditions

443 were conducted with standard three-electrode configuration and pyrite cubic working

444 electrodes cut from natural pyrite minerals. Microbial mediated anaerobic pyrite

445 oxidation experiments were carried out with three main microbial treatments

446 considering microbes under starved (Mos), pyrite (1.0 g/L) addition (Ctrl), and both

447 pyrite $(1.0 \mathrm{~g} / \mathrm{L})$ and EDTA $(5.0 \mathrm{mM})$ addition $(\mathrm{Rec})$ conditions. Detailed methods are

448 provided in the SI Appendix.

\section{Acknowledgement}

450 The authors acknowledge financial support from the National Natural Science

451 Foundation of China (NSFC) (No. 51578519), the Major Science and Technology

452 Program for Water Pollution Control and Treatment (No. 2017ZX07202002), and the

453 Fundamental Research Funds for the Central Universities (No. 2652018204).

\section{Supporting Information}

455 The supporting information includes text, figure S1-S12, table S1-S3 and dataset S1 for

456 the detailed materials and methods, detailed experimental design, reproduction of the

457 main experiment, and analysis of related additional experiments. 
(1) Rickard, D.; Luther, G. W. Chemistry of Iron Sulfides. Chemical Reviews. 2007, pp 514-562. https://doi.org/10.1021/cr0503658.

(2) Canfield, D. E.; Kristensen, E.; Thamdrup, B. The Sulfur Cycle. Adv. Mar. Biol. 2005. https://doi.org/10.1016/S0065-2881(05)48009-8.

(3) Canfield, D. E. A New Model for Proterozoic Ocean Chemistry. Nature 1998. https://doi.org/10.1038/24839.

(4) Lyons, T. W.; Reinhard, C. T.; Planavsky, N. J. The Rise of Oxygen in Earth's Early Ocean and Atmosphere. Nature. 2014. https://doi.org/10.1038/nature13068.

(5) Schippers, A. Biogeochemistry of Metal Sulfide Oxidation in Mining Environments, Sediments, and Soils. In Special Paper of the Geological Society of America; 2004. https://doi.org/10.1130/0-8137-2379-5.49.

(6) Mazumdar, A.; Goldberg, T.; Strauss, H. Abiotic Oxidation of Pyrite by Fe(III) in Acidic Media and Its Implications for Sulfur Isotope Measurements of LatticeBound Sulfate in Sediments. Chem. Geol. 2008. https://doi.org/10.1016/j.chemgeo.2008.03.014.

(7) Chen, Y. T.; Li, J. T.; Chen, L. X.; Hua, Z. S.; Huang, L. N.; Liu, J.; Xu, B. B.; Liao, B.; Shu, W. S. Biogeochemical Processes Governing Natural Pyrite Oxidation and Release of Acid Metalliferous Drainage. Environ. Sci. Technol. 2014. https://doi.org/10.1021/es500154z.

(8) Seibert, S.; Atteia, O.; Ursula Salmon, S.; Siade, A.; Douglas, G.; Prommer, H. Identification and Quantification of Redox and PH Buffering Processes in a Heterogeneous, Low Carbonate Aquifer during Managed Aquifer Recharge. Water Resour. Res. 2016. https://doi.org/10.1002/2015WR017802.

(9) Zhang, Y. C.; Slomp, C. P.; Broers, H. P.; Passier, H. F.; Cappellen, P. Van. Denitrification Coupled to Pyrite Oxidation and Changes in Groundwater Quality in a Shallow Sandy Aquifer. Geochim. Cosmochim. Acta 2009. https://doi.org/10.1016/j.gca.2009.08.026.

(10) Pauwels, H.; Foucher, J. C.; Kloppmann, W. Denitrification and Mixing in a Schist Aquifer: Influence on Water Chemistry and Isotopes. Chem. Geol. 2000. https://doi.org/10.1016/S0009-2541(00)00201-1.

(11) Postma, D.; Boesen, C.; Kristiansen, H.; Larsen, F. Nitrate Reduction in an Unconfined Sandy Aquifer: Water Chemistry, Reduction Processes, and Geochemical Modeling. Water Resour. Res. 1991. https://doi.org/10.1029/91WR00989.

(12) Jessen, S.; Postma, D.; Thorling, L.; Müller, S.; Leskelä, J.; Engesgaard, P. Decadal Variations in Groundwater Quality: A Legacy from Nitrate Leaching and Denitrification by Pyrite in a Sandy Aquifer. Water Resour. Res. 2017. https://doi.org/10.1002/2016WR018995.

(13) Van Beek, C. G. E. M.; Hettinga, F. A. M.; Straatman, R. The Effects of Manure Spreading and Acid Deposition upon Groundwater Quality at Vierlingsbeek, the Netherlands; IAHS Publ, 1989. 
(14) Van Berk, W.; Fu, Y. Redox Roll-Front Mobilization of Geogenic Uranium by Nitrate Input into Aquifers: Risks for Groundwater Resources. Environ. Sci. Technol. 2017. https://doi.org/10.1021/acs.est.6b01569.

(15) Beller, H. R.; Zhou, P.; Legler, T. C.; Chakicherla, A.; Kane, S.; Letain, T. E.; O'Day, P. A. Genome-Enabled Studies of Anaerobic, Nitrate-Dependent Oxidation in the Chemolithoautotrophic Bacterium Thiobacillus Denitrificans. Front. Microbiol. 2013. https://doi.org/10.3389/fmicb.2013.00249.

(16) Schwientek, M.; Einsiedl, F.; Stichler, W.; Stögbauer, A.; Strauss, H.; Maloszewski, P. Evidence for Denitrification Regulated by Pyrite Oxidation in a Heterogeneous Porous Groundwater System. Chem. Geol. 2008. https://doi.org/10.1016/j.chemgeo.2008.06.005.

(17) Bosch, J.; Lee, K.-Y.; Jordan, G.; Kim, K.-W.; Meckenstock, R. U. Anaerobic, Nitrate-Dependent Oxidation of Pyrite Nanoparticles by Thiobacillus Denitrificans. Environ. Sci. Technol. 2012, 46 (4), 2095-2101. https://doi.org/10.1021/es2022329.

(18) Rohwerder, T.; Gehrke, T.; Kinzler, K.; Sand, W. Bioleaching Review Part A: Appl. Microbiol. Biotechnol. 2003. https://doi.org/10.1007/s00253-003-1448-7.

(19) Yan, R.; Kappler, A.; Peiffer, S. Interference of Nitrite with Pyrite under Acidic Conditions: Implications for Studies of Chemolithotrophic Denitrification. Environ. Sci. Technol. 2015, 49 (19), 11403-11410. https://doi.org/10.1021/acs.est.5b02981.

(20) Pu, J.; Feng, C.; Liu, Y.; Li, R.; Kong, Z.; Chen, N.; Tong, S.; Hao, C.; Liu, Y. Pyrite-Based Autotrophic Denitrification for Remediation of Nitrate Contaminated Groundwater. Bioresour. Technol. 2014, 173, 117-123. https://doi.org/10.1016/j.biortech.2014.09.092.

(21) Tong, S.; Rodriguez-Gonzalez, L. C.; Feng, C.; Ergas, S. J. Comparison of Particulate Pyrite Autotrophic Denitrification (PPAD) and Sulfur Oxidizing Denitrification (SOD) for Treatment of Nitrified Wastewater. Water Sci. Technol. 2017, 75 (1), 239-246. https://doi.org/10.2166/wst.2016.502.

(22) Torrentó, C.; Urmeneta, J.; Otero, N.; Soler, A.; Viñas, M.; Cama, J. Enhanced Denitrification in Groundwater and Sediments from a Nitrate-Contaminated Aquifer after Addition of Pyrite. Chem. Geol. 2011, 287 (1-2), 90-101. https://doi.org/10.1016/j.chemgeo.2011.06.002.

(23) Xu, B.; Shi, L.; Zhong, H.; Wang, K. The Performance of Pyrite-Based Autotrophic Denitrification Column for Permeable Reactive Barrier under Natural Environment. Bioresour. Technol. 2019, 121763. https://doi.org/10.1016/j.biortech.2019.121763.

(24) Ge, Z.; Wei, D.; Zhang, J.; Hu, J.; Liu, Z.; Li, R. Natural Pyrite to Enhance Simultaneous Long-Term Nitrogen and Phosphorus Removal in Constructed Wetland: Three Years of Pilot Study. Water Res. 2019, 148, 153-161. https://doi.org/10.1016/j.watres.2018.10.037.

(25) Tong, S.; Stocks, J. L.; Rodriguez-Gonzalez, L. C.; Feng, C.; Ergas, S. J. Effect 
of Oyster Shell Medium and Organic Substrate on the Performance of a Particulate Pyrite Autotrophic Denitrification (PPAD) Process. Bioresour. Technol. 2017, 244, 296-303. https://doi.org/10.1016/j.biortech.2017.07.109.

(26) Xiao, Z.; Wang, W.; Chen, D.; Yu, Y.; Huang, H. PH Control of an Upflow PyriteOxidizing Denitrifying Bioreactor via Electrohydrogenesis. Bioresour. Technol. 2019, 281, 41-47. https://doi.org/10.1016/j.biortech.2019.02.069.

(27) Valdés, J.; Pedroso, I.; Quatrini, R.; Dodson, R. J.; Tettelin, H.; Blake, R.; Eisen, J. A.; Holmes, D. S. Acidithiobacillus Ferrooxidans Metabolism: From Genome Sequence to Industrial Applications. BMC Genomics 2008. https://doi.org/10.1186/1471-2164-9-597.

(28) Holmes, P. R.; Crundwell, F. K. The Kinetics of the Oxidation of Pyrite by Ferric Ions and Dissolved Oxygen: An Electrochemical Study. Geochim. Cosmochim. Acta 2000. https://doi.org/10.1016/S0016-7037(99)00296-3.

(29) Dos Santos, E. C.; De Mendonça Silva, J. C.; Duarte, H. A. Pyrite Oxidation Mechanism by Oxygen in Aqueous Medium. J. Phys. Chem. C 2016. https://doi.org/10.1021/acs.jpcc.5b10949.

(30) Xiao, Y.; Liu, X.; Liang, Y.; Niu, J.; Zhang, X.; Ma, L.; Hao, X.; Gu, Y.; Yin, H. Insights into Functional Genes and Taxonomical/Phylogenetic Diversity of Microbial Communities in Biological Heap Leaching System and Their Correlation with Functions. Appl. Microbiol. Biotechnol. 2016. https://doi.org/10.1007/s00253-016-7819-7.

(31) Bosch, J.; Meckenstock, R. U. Rates and Potential Mechanism of Anaerobic Nitrate-Dependent Microbial Pyrite Oxidation. In Biochemical Society Transactions; 2012; Vol. 40, pp 1280-1283. https://doi.org/10.1042/BST20120102.

(32) Kracke, F.; Vassilev, I.; Krömer, J. O. Microbial Electron Transport and Energy Conservation - The Foundation for Optimizing Bioelectrochemical Systems. Frontiers in Microbiology. 2015. https://doi.org/10.3389/fmicb.2015.00575.

(33) Taran, O. Electron Transfer between Electrically Conductive Minerals and Quinones. Front. Chem. 2017. https://doi.org/10.3389/fchem.2017.00049.

(34) Batchelor-McAuley, C.; Gonçalves, L. M.; Xiong, L.; Barros, A. A.; Compton, R. G. Controlling Voltammetric Responses by Electrode Modification; Using Adsorbed Acetone to Switch Graphite Surfaces between Adsorptive and Diffusive Modes. Chem. Commun. 2010, 46 (47), 9037-9039. https://doi.org/10.1039/C0CC03961F.

(35) Gupta, R.; K. Guin, S.; K. Aggarwal, S. A Mechanistic Study on the Electrocatalysis of the $\mathrm{Pu}$ ( Iv )/Pu( Iii ) Redox Reaction at a Platinum Electrode Modified with Single-Walled Carbon Nanotubes (SWCNTs) and Polyaniline (PANI). RSC Adv. 2012, $2 \quad$ (5), 1810-1819. https://doi.org/10.1039/C1RA01010G.

(36) Chang, Y.; Gu, W.; McLandsborough, L. Low Concentration of Ethylenediaminetetraacetic Acid (EDTA) Affects Biofilm Formation of Listeria 
Monocytogenes by Inhibiting Its Initial Adherence. Food Microbiol. 2012.

586

587

588

589

590

591

592

593

594

595

596

597

598

599

600

601

602

603

604

605

606

607

608

609

610

611

612

613

614

615

616

617

618

619

620

621

622

623

624

625

626 https://doi.org/10.1016/j.fm.2011.07.009.

(37) Nayfach, S.; Shi, Z. J.; Seshadri, R.; Pollard, K. S.; Kyrpides, N. C. New Insights from Uncultivated Genomes of the Global Human Gut Microbiome. Nature 2019, 568 (7753), 505.

(38) Huerta-Cepas, J.; Szklarczyk, D.; Heller, D.; Hernández-Plaza, A.; Forslund, S. K.; Cook, H.; Mende, D. R.; Letunic, I.; Rattei, T.; Jensen, L. J.; et al. EggNOG 5.0: A Hierarchical, Functionally and Phylogenetically Annotated Orthology Resource Based on 5090 Organisms and 2502 Viruses. Nucleic Acids Res. 2019, 47 (D1), D309-D314. https://doi.org/10.1093/nar/gky1085.

(39) Kanehisa, M.; Araki, M.; Goto, S.; Hattori, M.; Hirakawa, M.; Itoh, M.; Katayama, T.; Kawashima, S.; Okuda, S.; Tokimatsu, T.; et al. KEGG for Linking Genomes to Life and the Environment. Nucleic Acids Res. 2008, 36 (suppl_1), D480-D484. https://doi.org/10.1093/nar/gkm882.

(40) Sun, W.; Hu, Y.; Qiu, G.; Qin, W.; Liu, Y. A Study on Electrochemical Corrosion of Surface Reaction of Pyrite in High Alkali Environment. Min. Metall. Eng. 2002, 22 (04), 51-54.

(41) Chiriță, P.; Schlegel, M. L. Pyrite Oxidation in Air-Equilibrated Solutions: An $\begin{array}{lllll}\text { Electrochemical Study. } & \text { Chem. }\end{array}$ https://doi.org/10.1016/j.chemgeo.2017.08.023.

(42) Zheng, K.; Li, H.; Wang, L.; Wen, X.; Liu, Q. Pyrite Oxidation under Simulated Acid Rain Weathering Conditions. Environ. Sci. Pollut. Res. 2017. https://doi.org/10.1007/s11356-017-9804-9.

(43) Tao, D. P.; Richardson, P. E.; Luttrell, G. H.; Yoon, R. H. Electrochemical Studies of Pyrite Oxidation and Reduction Using Freshly-Fractured Electrodes and Rotating Ring-Disc Electrodes. Electrochimica Acta 2003. https://doi.org/10.1016/S0013-4686(03)00482-1.

(44) Sato, M.; Mooney, H. M. THE ELECTROCHEMICAL MECHANISM OF SULFIDE SELF-POTENTIALS. GEOPHYSICS 1960. https://doi.org/10.1190/1.1438689.

(45) Tu, Z.; Wan, J.; Guo, C.; Fan, C.; Zhang, T.; Lu, G.; Reinfelder, J. R.; Dang, Z. Electrochemical Oxidation of Pyrite in PH 2 Electrolyte. Electrochimica Acta 2017. https://doi.org/10.1016/j.electacta.2017.04.049.

(46) Liu, C.; Jia, Y.; Sun, H.; Tan, Q.; Niu, X.; Leng, X.; Ruan, R. Limited Role of Sessile Acidophiles in Pyrite Oxidation below Redox Potential of 650 MV. Sci. Rep. 2017, 7 (1), 1-8. https://doi.org/10.1038/s41598-017-04420-2.

(47) Vaclavkova, S.; Schultz-Jensen, N.; Jacobsen, O. S.; Elberling, B.; Aamand, J. Nitrate-Controlled Anaerobic Oxidation of Pyrite by Thiobacillus Cultures. $\begin{array}{lllll}\text { Geomicrobiol. } & \text { J. } & \mathbf{2 0 1 5}, & 32 & \text { (5), }\end{array}$ https://doi.org/10.1080/01490451.2014.940633.

(48) Torrentó, C.; Cama, J.; Urmeneta, J.; Otero, N.; Soler, A. Denitrification of Groundwater with Pyrite and Thiobacillus Denitrificans. Chem. Geol. 2010. 
https://doi.org/10.1016/j.chemgeo.2010.09.003.

(49) Yan, R.; Kappler, A.; Muehe, E. M.; Knorr, K.-H.; Horn, M. A.; Poser, A.; Lohmayer, R.; Peiffer, S. Effect of Reduced Sulfur Species on Chemolithoautotrophic Pyrite Oxidation with Nitrate. Geomicrobiol. J. 2019, 36 (1), 19-29. https://doi.org/10.1080/01490451.2018.1489915.

(50) Tong, S.; Rodriguez-Gonzalez, L. C.; Payne, K. A.; Stocks, J. L.; Feng, C.; Ergas, S. J. Effect of Pyrite Pretreatment, Particle Size, Dose, and Biomass Concentration on Particulate Pyrite Autotrophic Denitrification of Nitrified Domestic Wastewater. Environ. Eng. Sci. 2018, 35 (8), 875-886. https://doi.org/10.1089/ees.2017.0295.

(51) Zhu, G. B.; Peng, Y. Z.; Guo, J. H. Biological Nitrogen Removal with Nitrification and Denitrification via Nitrite Pathway. Harbin Gongye Daxue XuebaoJournal Harbin Inst. Technol. 2008.

(52) Glass, C.; Silverstein, J. Denitrification Kinetics of High Nitrate Concentration Water: PH Effect on Inhibition and Nitrite Accumulation. Water Res. 1998. https://doi.org/10.1016/S0043-1354(97)00260-1.

(53) Torrentó, C.; Urmeneta, J.; Edwards, K. J.; Cama, J. Characterization of Attachment and Growth of Thiobacillus Denitrificans on Pyrite Surfaces. $\begin{array}{llllll}\text { Geomicrobiol. } & \text { J. } & \mathbf{2 0 1 2}, & 29 & \text { (4), }\end{array}$ https://doi.org/10.1080/01490451.2011.575912.

(54) Percak-Dennett, E.; He, S.; Converse, B.; Konishi, H.; Xu, H.; Corcoran, A.; Noguera, D.; Chan, C.; Bhattacharyya, A.; Borch, T.; et al. Microbial Acceleration of Aerobic Pyrite Oxidation at Circumneutral PH. Geobiology 2017, 15 (5), 690-703. https://doi.org/10.1111/gbi.12241.

(55) Zhou, Y.; Mai, W.; Liang, J.; Dai, J.; Niu, Y.; Li, W.; Tang, Q. Nitrogen Removal Performance of a Sulfur/Pyrite Autotrophic Denitrification System. Environ. Sci. 2019, 40 (04), 1885-1891.

(56) Li, F.; Shi, C.; Li, H.; Yuan, R.; Ma, F. Impact of Starvation Conditions on Biological Community Structure in Sulfur Autotrophic Denitrification Reactor. Environ. Sci. 2017, 38 (03), 1109-1115.

(57) Flemming, H. C.; Wuertz, S. Bacteria and Archaea on Earth and Their Abundance in Biofilms. Nat. Rev. Microbiol. 2019. https://doi.org/10.1038/s41579-019-0158-9.

(58) Valdés, J.; Pedroso, I.; Quatrini, R.; Dodson, R. J.; Tettelin, H.; Blake, R.; Eisen, J. A.; Holmes, D. S. Acidithiobacillus Ferrooxidans Metabolism: From Genome Sequence to Industrial Applications. BMC Genomics 2008, 9 (1), 597. https://doi.org/10/d6fjj7.

(59) Tan, S.; Liu, J.; Fang, Y.; Hedlund, B. P.; Lian, Z.-H.; Huang, L.-Y.; Li, J.-T.; Huang, L.-N.; Li, W.-J.; Jiang, H.-C.; et al. Insights into Ecological Role of a New Deltaproteobacterial Order \{Candidatus\} \{Acidulodesulfobacterales\} by Metagenomics and Metatranscriptomics. ISME J. 2019. https://doi.org/10.1038/s41396-019-0415-y. 
(60) Mariën, A.; Bleyen, N.; Aerts, S.; Valcke, E. The Study of Abiotic Reduction of Nitrate and Nitrite in Boom Clay. Phys. Chem. Earth Parts ABC 2011, 36 (1718), 1639-1647.

(61) Bleyen, N.; Mariën, A.; Valcke, E. The Geochemical Perturbation of Boom Clay

(62) Hoving, A. L.; Sander, M.; Bruggeman, C.; Behrends, T. Redox Properties of

(63) Brantley, S. L.; Holleran, M. E.; Jin, L.; Bazilevskaya, E. Probing Deep

(67) Harrold, Z. R.; Skidmore, M. L.; Hamilton, T. L.; Desch, L.; Amada, K.; van

(65) Boyd, E. S.; Hamilton, T. L.; Havig, J. R.; Skidmore, M. L.; Shock, E. L. Chemolithotrophic Primary Production in a Subglacial Ecosystem. Appl.
Environ.
Microbiol.
2014,
80
(19),
6146-6153.

(66) Hindshaw, R. S.; Heaton, T. H. E.; Boyd, E. S.; Lindsay, M. R.; Tipper, E. T. Influence of Glaciation on Mechanisms of Mineral Weathering in Two High Arctic Catchments. Chem. Geol. 2016, 420, 37-50. https://doi.org/10.1016/j.chemgeo.2015.11.004. 